O. Snidevych, PhD (Law), Associate prof.

Taras Shevchenko National University of Kyiv, Kyiv, Ukraine

\title{
MEASURES FOR THE ENFORCEMENT OF JUDGMENTS AS MANIFESTATION OF DIFFERENTIATION OF EXECUTIVE PROCEDURAL FORM
}

The article deals with the analysis of the concept of the enforcement of judgments as the manifestation of differentiation of the executive procedural form.

It is stipulated that the executive procedural form in the execution of court decisions and decisions of other authorities is not the same for all enforcement proceedings. The executor and other participants of the enforcement proceeding perform different functions in the enforcement proceeding. It is suggested that in the enforcement process the measures for the enforcement of judgment, stipulated by the legislation on enforcement proceedings are the most striking manifestation of the executive procedural form.

In legal studies the concept of the measures for the enforcement of judgments remains controversial. The author distinguishes three approaches to understanding of this concept, he calls them substantive-legal, substantive-procedural and procedural.

According to the substantive-legal approach, measures for enforcement of judgments are a sanction for non-compliance. Under the substantive-procedural approach, measures for the enforcement of judgments are the means of implementation of sanctions. Based on the procedural approach, measures for enforcement of judgments are considered as a set of procedural actions to enforce the decision. It is concluded that each of these approaches is justified and all of them together characterize the measures for enforcement of judgments as a multifaceted phenomenon. The article focuses on more detailed analysis on the enforcement of judgments in procedural sense.

It is proved that the measures for the enforcement of judgments are a category that differentiates the executive procedural form. These measures are a certain procedural pattern of enforcement, a distinct set of procedural actions, connected with the enforcement of different decisions. Every writ of execution should be performed within the frames of a certain measure for the enforcement of judgments.

As the result of the research the author formulates his own definitions of the measures for the enforcement of judgments.

Keywords: enforcement proceeding, executive procedural form, enforcement procedure, means of rights protection, executor, writ of execution, measures for enforcement of judgments.

Bulletin of Taras Shevchenko National University of Kyiv. Legal Studies, 2021; 1 (116): 57-61

УдК: $341.01+342$

DOI: https:doi.org/10.17721/1728-2195/2021/1.116-12
ISSN 1728-2195

(C) Taras Shevchenko National University of Kyiv, Publishing center "Kyiv University", 2020

О. Стрєльцова, д-р юрид. наук, доц. ORCID ID: 0000-0002-0907-2049

Київський національний університет імені Тараса Шевченка, Київ, Україна

\section{КОНСТИТУЦІОНАЛІЗАЦІЯ СПІВРОБІТНИЦТВА УКРАЇНИ 3 ЄС НА ПІДСТАВІ УГОДИ ПРО АСОЦІАЦІЮ: ПЕРСПЕКТИВИ РОЗВИТКУ}

Досліджується процес конституціоналізації асоціативних відносин між Україною та Європейським Союзом. Автор виокремлює й розкриває два основні аспекти цього процесу: змістовний та імплементаційний. Визначається, що змістовна конституціоналізація по своїй суті є конституційною модернізацією, у ході якої відбувається змістовне оновлення положень Конституції з метою формування конституційних засад для подальшої демократизації суспільно-політичного життя в Україні, наближення національної політико-правової системи до європейських цінностей $і$ принципів, удосконалення внутрішньодержавної законодавчої бази. Імплементаційний аспект конституціоналізації полягає в цілеспрямованому формуванні конституційних передумов для імплементації положень Угоди про асоціацію до національної системи права. Автор вважає, що здійснення як змістовної, так і імплементаційної конституціоналізації асоціації України з ЄС можна реалізувати лише шляхом включення цього процесу безпосередньо в контекст конституційної реформи в Україні.

Звертається увага на певні проблеми реформування Конституції України у зв'язку із забезпеченням європейської інтеграції та висловлюються критичні застереження, пов'язані з доповненням Конституції положеннями щодо стратегічного курсу України на довготривалу перспективу.

Ключові слова: Конституція України, конституційна реформа, конституціоналізація, Європейський Союз, Угода про асоціацію між Украӥною та $Є C$.

ВСтУП. Підписавши Угоду про асоціацію з Європейським Союзом (далі - ЄС), Україна взяла на себе зобов'язання вдосконалити внутрішньодержавну правову базу, привести її у відповідність із європейськими стандартами. У цьому контексті чи не найбільшої уваги потребують положення Основного закону держави - Конституції. І це зрозуміло, оскільки саме в Конституції концентровано відображені підходи держави до міжнародного співробітництва, саме вона $є$ тим елементом правової системи, що здатен ефективно регулювати діяльність як у внутрішньодержавній, так і в зовнішньополітичній сферах, сприяти належному захисту національних інтересів.

3 іншого боку, проблеми зміни норм Основного закону, скасування чинних або включення нових положень, що регламентують питання, пов'язані з міжнародними відносинами, актуалізуються у зв'язку із загальними процесами конституційного реформування, зок- рема із внесенням в лютому 2019 р. до Конституції України змін, які визначили стратегічний курс держави на набуття повноправного членства України в ЄС.

Виходячи із зазначеного, метою статті $\boldsymbol{\epsilon}$ дослідження змістовного та імплементаційного аспектів конституціоналізації асоціації України з ЄС як основи цього процесу й аналіз проблемних аспектів і подальших перспектив реалізації визначеного в Конституції України стратегічного курсу нашої держави на набуття повноправного членства в ЄС.

Питання конституційних змін не є новим для України і вже неодноразово ставало як предметом політичних дискусій, так і об'єктом наукових досліджень. До характеристики тих чи інших аспектів цього процесу зверталися у своїх дослідженнях такі вітчизняні науковці, як Ю. Барабаш, Ю. Волошин, В. Кампо, А. Крусян, М. Орзіх, Н. Пархоменко, С. Погребняк, Т. Подорожна, О. Скрипнюк, В. Шамрай, Я. Чернопищук та ін. Разом із тим, роз- 
горнутого теоретичного обґрунтування він усе ще не отримав. Підтвердженням цієї тези є фрагментарність і суперечливість підходів до характеристики конституціоналізації процесу асоціації України з ЄС, що наводяться в юридичній літературі, а також деякі розбіжності в розумінні його сутнісного та змістовного наповнення.

Водночас розвиток асоціативних відносин із ЄС викликає необхідність детального аналізу здійснених i планованих конституційних змін із метою їхнього співвіднесення із задекларованими євроінтеграційними прагненнями нашої держави. Як правильно наголошував О. Задорожній, розмежування конституційного процесу й різноманітних аспектів міжнародного права $€$ помилковим, адже тільки їхній інтегрований розгляд дозволить розробити цілісну стратегію конституційної реформи в Україні [1, с. 29].

ВИКЛАД ОСНОВНОГО МАТЕРІАЛУ. ВОчевИДЬ, УСпішність процесу конституційного реформування в Україні прямо пропорційна його відповідності ряду умов, а саме: концептуальній обґрунтованості; системності; транспарентності; врахуванню національних особливостей конституційно-правового розвитку та фоормування конституційної традиції; відповідності формальним процедурним вимогам (легальності); суспільному визнанню й підтримці конституційних перетворень (легітимності); урахуванню внутрішніх і зовнішніх чинників політичного та соціально-економічного характеру для мінімізації їхнього впливу на конституційно-правові процеси.

Проте водночас здійснення будь-яких конституційних перетворень насамперед вимагає визначення двох ключових позицій, а саме: хто є, так би мовити, "замовником" здійснених і планованих конституційних змін і яка водночас переслідується мета? Як здається, замовником конституційної реформи в нашій країні $\epsilon$ народ України, який прагне змінити підходи до організації держави, функціонування ії апарату, її взаємодії із суспільством. Виходячи з цих вимог українського народу, метою конституційного реформування варто вважати створення конституційної системи обмеженого правління як практичне втілення доктрини конституціоналізму, унаслідок чого Україна має стати конституційною державою [2, с. 48].

Вбачається, що досягнення цієї мети логічно корелюється з реалізацією цілей і завдань Угоди про асоціацію між Україною та ЄС. Зокрема ст. 4 Угоди встановлює, що однією $з$ цілей політичного діалогу Сторін $€$ "зміцнення поваги до демократичних принципів, верховенства права та належного врядування, прав людини та основоположних свобод, ... а також внесок у консолідацію внутрішніх політичних реформ" [3].

На нашу думку (яку ми також обґрунтовували у своїх наукових дослідженнях [4; 5]), успішне виконання визначених Угодою завдань потребує спрямування процесів конституціоналізації безпосередньо у сферу регулювання цих відносин, що зумовлює об'єктивну необхідність їхньої регламентації та забезпечення на найвищому - конституційно-правовому рівні. Ідеться про те, що самої лише конституційної формалізації європейського курсу подальшого розвитку країни вочевидь недостатньо для того, щоб реалізувати інтеграційні прагнення України. Це можливо лише у випадку створення політико-правової й економічної систем, сумісних із європейськими, що вимагає уніфікації конституційних підходів до регулювання пріоритетних конституційних інститутів - прав і свобод людини, громадянського суспільства, правосуддя, механізмів децентралізації вла- ди, парламентаризму, ринкової економіки. 3 іншого боку, процес конституціоналізації напряму залежить від послідовного вираження нормативного змісту Конституції України в поточному законодавстві, що деталізує й розвиває ії приписи [6, с. 72], а також від створення відповідних організаційних засад, необхідних для ефективної правотворчості та правозастосування. Завдяки цьому норми Угоди про асоціацію мають стати своєрідним орієнтиром правової політики держави, а всі національні правові акти повинні тлумачитись і застосовуватись у максимальній відповідності до її положень.

У цьому контексті конституціоналізація асоціації України з $€ С$ є багатокомпонентним процесом, здійснення якого має так чи інакше охоплювати всі рівні правової системи. Практичний аспект конституціоналізації процесу асоціації України з ЄС виявляється через динамічну сукупність заходів організаційно-правового характеру, спрямованих на реалізацію мети європейської інтеграції України. На нормативному рівні правової системи такі заходи мають здійснюватися за трьома основними модусами (напрямами).

По-перше, базовою передумовою конституціоналізації асоціативних відносин України та $Є С €$ реформування змістовних та імплементаційних засад Основного закону України для забезпечення конституційного супроводу цього процесу.

По-друге, важливим елементом конституціоналізації асоціативних відносин України та $€ C €$ конкретизація й деталізація конституційних норм і принципів у системах позитивного права і законодавства (передусім у тих законодавчих і підзаконних нормативноправових актах, які спрямовані на гармонізацію національного права із правом $€ C)$.

По-третє, у процесі реалізації положень Угоди про асоціацію визначального значення набуває правотлумачна та правозастосовна діяльність національних органів державної влади, і особливо судових органів конституційної й загальної юрисдикції.

Проте, національна конституціоналізація процесу асоціації опосередковується всіма видами юридичної діяльності держави (правотворчою, правоінтерпретаційною та правозастосовною), що пов'язано з необхідністю забезпечення окремих осіб (фрізичних і юридичних) правовими засобами безпосереднього використання норм Угоди про асоціацію. Усі ці напрями конституціоналізації $€$ взаємопов'язаними та взаємодоповнюючими, проте такий взаємозв'язок має ієрархічний характер. Він виявляється в тому, що в будь-якій демократичній, правовій державі конституція $€$ актом вищої юридичної сили, її норми займають головне положення відносно норм інших правових актів, а їхня дія визначається принципом верховенства у правовій системі, який передбачає здійснення нормотворчої та правозастосовної діяльності в державі на основі та відповідно до її положень [7, с. 69-70].

Разом із тим, жодна конституція, як би детально вона не врегульовувала суспільні відносини, не в змозі охопити весь спектр таких відносин, оскільки, з одного боку, конституція має стабільний характер, а суспільні відносини - динамічний, а з іншого - коло цих відносин $€$ надзвичайно широким. Тому певна їхня частина регламентується законодавцем за допомогою законів, які мають відповідати принципам, цілям, деклараціям конституції, тобто її духу [8, с. 545-546]. Так само похідними від норм і принципів Конституції України $є$ правот- 
лумачні і правозастосовні акти судів конституційної й загальної юрисдикції.

Тому, на нашу думку, перший із напрямів конституціоналізації процесу асоціації - тобто на рівні Основного закону, усе ж таки є первинним, оскільки саме Конституція України, будучи наділеною в межах національної правової системи верховенством і найвищою юридичною силою, визначає основи правового регулювання асоціативних відносин і тим самим надає імпульсу та спрямовує відповідні процеси на інших рівнях, які варто розглядати як вторинну конституціоналізацію. Водночас первинна конституціоналізація процесу асоціації України з ЄС має два аспекти: змістовний та імплементаційний.

Змістовна конституціоналізація по своїй суті $€$ конституційною модернізацією, у ході якої відбувається змістовне оновлення положень Основного закону з метою формування конституційних засад для подальшої демократизації суспільно-політичного життя в Україні, наближення національної політико-правової системи до європейських цінностей і принципів, удосконалення внутрішньодержавної законодавчої бази. Це ті зміни, які вже тривалий час стоять на порядку денному в контексті проведення конституційної реформи в Україні. Проте водночас - це ті конституційні перетворення, на проведенні яких наполягає $€ C$, розглядаючи їх як необхідну умову подальшого розвитку асоціативних відносин із нашою державою та реалізації її євроінтеграційних прагнень [4].

Відповідний підхід відображено безпосередньо в тексті Угоди про асоціацію між Україною та ЄС. Так, ст.ст. 3 і 6 Угоди визначають прагнення України та ЄС співпрацювати з метою забезпечення того, щоб їхня внутрішня політика ґрунтувалася на спільних для них принципах, зокрема таких, як стабільність і дієвість демократичних інституцій, верховенство права та повага до прав людини й основоположних свобод, належне урядування, ринкова економіка, збалансований розвиток та ін.

Конкретизуючи ці положення, ст. 14 Розділу III "Юстиція, свобода та безпека" передбачає, що в межах співробітництва у сфері юстиції, свободи та безпеки Сторони надають особливого значення утвердженню верховенства права й укріпленню інституцій усіх рівнів у сфері управління загалом і правоохоронних і судових органів зокрема. Підкреслюється, що серед іншого, співробітництво Сторін буде спрямоване на зміцнення судової влади, підвищення її ефективності, гарантування ії незалежності й неупередженості та боротьбу з корупцією [9].

Як бачимо, саме конституційна реформа має визначальне значення для проведення всіх інших заходів, зокрема, галузевих реформ, в основу яких має покладатися принцип конституціоналізації. Одним із пріоритетних завдань конституційної реформи на нинішньому етапі $\epsilon$ встановлення такого механізму державної влади, який би унеможливлював узурпацію влади будь-ким із вищих посадових осіб держави, і водночас забезпечував би єдність державної політики [10]. Реформа повинна була гарантувати забезпечення справедливого правосуддя, а також закласти основи для реформи місцевого самоврядування та децентралізації влади.

Виходячи з цих засад, пріоритетами змістовної конституціоналізації в аспекті процесу асоціації України з $€ C$ стали реформа правосуддя й децентралізація влади (реформа місцевого самоврядування). Загалом, саме в цих двох сфрерах зовнішні зобов'язання України цілком збіглись із внутрішньонаціональними інтересами. Виходячи із зовнішніх зобов'язань та внутрішньоде- ржавних пріоритетів, основним завданням змістовної конституціоналізації в аспекті процесу асоціації України з ЄС стала реформа Конституції України щодо правосуддя (2016) і напрацювання ряду проєктів і пропозицій у сфері децентралізації влади. Разом із тим, зміна тексту Конституції України, будучи базовим фактором конституціоналізації процесу асоціації України з $€ С$, не зводиться лише до формальної конституційної легалізації та не вичерпується реформуванням системи правосуддя та реорганізацією місцевого самоврядування в Україні [11, с. 9-11]. Отже, подальша конституціоналізація національної правової системи є багатоплановим процесом, ефективність якого визначатиметься підвищенням конституційної якості та рівня регулювання суспільних відносин у державі.

Другий - імплементаційний аспект конституціоналізації, полягає у цілеспрямованому формуванні конституційних передумов для імплементації положень Угоди про асоціацію до вітчизняної системи права. Імплементаційна конституціоналізація передбачає всю сукупність заходів щодо реформування конституційного законодавства 3 метою створення належних конституційних засад для імплементації (забезпечення дії та реалізації) положень Угоди про асоціацію до національного правопорядку України. Фактично, імплементаційний аспект конституціоналізації асоціативних відносин України та ЄС полягає в конституційному опосередкуванні та забезпеченні реалізації норм Угоди про асоціацію в межах національного правопорядку України. Ключовими показниками імплементаційної конституціоналізації асоціативних відносин України та $€ C €$, поперше, закріплення на рівні Основного закону засад зовнішньополітичної діяльності України (зокрема проєвропейського зовнішньополітичного курсу держави), що $€$ передумовою та своєрідною конституційно-правовою гарантією наступництва й послідовності у проведенні імплементаційних заходів у сфері асоціації України та $\epsilon \mathrm{i}$, по-друге, удосконалення конституційних положень щодо взаємодії національного та міжнародного права, зокрема тих, які регламентують питання імплементації міжнародних договорів до національної системи права (передусім ст. 9 Конституції України).

Що стосується визначення в Конституції України стратегічного курсу держави на набуття повноправного членства України в ЄС, варто зазначити, що дискусія щодо необхідності закріплення в преамбулі або в розділі I Основного Закону положень про європейський вибір України розгорнулась у вітчизняних наукових колах задовго до офріційного внесення змін до Конституції України. Фахівці й експерти, посилаючись на Декларацію про державний суверенітет України 1990 р., вказували, що вона містить положення про те, що "Українська РСР виступає рівноправним учасником міжнародного спілкування, активно сприяє зміцненню загального миру і міжнародної безпеки, безпосередньо бере участь у загальноєвропейському процесі та європейських структурах" (курсив наш. - О. С.) [12; 4]. Тим самим відзначалося, що в Декларації, хоч і в загальному вигляді, але встановлюються певні засади європейської спрямованості зовнішньополітичної діяльності України, і наголошувалося на тому, що саме цього бракувало тогочасній редакції Основного Закону.

У певному сенсі такій підхід мав під собою об'єктивне підґрунтя, адже зміна політичних сил у владі (і особливо в особі Президента України) щоразу зумовлювала певні корективи в зовнішньополітичній орієнтації та 
стратегії розвитку нашої держави. Так, за часів президентства Л. Кучми в основу зовнішньополітичної діяльності України була покладена так звана політика "багатовекторного балансування": з одного боку, пріоритетним напрямом зовнішньополітичної діяльності нашої держави проголошувалась європейська інтеграція, а 3 іншого - Україна брала участь у деяких інтеграційних проєктах на теренах СНД і будувала двосторонні відносини з Росією й іншими колишніми республіками Радянського Союзу на основі добросусідства, співробітництва і партнерства. Після Помаранчевої революції тогочасний новообраний Президент В. Ющенко віддав перевагу західному вектору співробітництва України в зовнішній сфрері. Натомість його опонент та наступний очільник держави В. Янукович, кардинально змінив зовнішні пріоритети України із західного на східний вектор, унаслідок чого намітилися тенденції руху України до євразійських інтеграційних структур, що в кінцевому підсумку призвело до відмови у підписанні Угоди про асоціацію між Україною та ЄС і стало одним із чинників Революції гідності 2014 р. Аналізуючи ці події, В. Муравйов зазначив, що включення "євроінтеграційної статті" до Конституції України сприяло б наступності у її внутрішній і зовнішній політиці, незалежно від зміни політичних сил у владі, та послідовності у поступальному розвитку нашої держави [13, с. 29].

Крім того, якщо проаналізувати зобов'язання в політичній, економічній та правовій сферах, що прийняла на себе Україна за Угодою про асоціацію, і особливо широкомасштабність і обсяг заходів, які необхідно здійснити, зокрема щодо адаптації національного законодавчого регулювання до стандартів $€ С$, стає зрозумілим, що такий підхід розрахований на довготривалу перспективу й потребує поетапності, стабільності та передбачуваності зовнішньополітичного вектора розвитку України.

Проте водночас потрібно висловити й певні застереження, пов'язані 3 доповненням Конституції положеннями щодо стратегічного курсу України на довготривалу перспективу.

По-перше, варто констатувати, що фріксація у преамбулі Основного закону євроінтеграційних прагнень нашої держави має винятково внутрішній, односторонній характер, оскільки Угода про асоціацію між Україною та ЄС зараз не надає Україні жодних перспектив членства в цьому міждержавному об'єднанні. У ній лише наголошується на визнанні Союзом європейського вибору та європейських прагнень України як європейської держави, що поділяє з ЄС спільну історію та цінності, а також визначається, що політична асоціація та економічна інтеграція України з ЄС залежатиме від прогресу в імплементації цієї Угоди та від досягнень України в забезпеченні поваги до спільних цінностей і наближенні до ЄС у політичній, економічній і правовій сорерах. Ці положення $€$ відображенням принципів кондиціональності та еволюціональності, які доволі часто використовуються Союзом у практиці регулювання асоціативних відносин, але водночас вони свідчать про те, що на відміну від Угод про стабілізацію й асоціацію з балканськими країнами чи навіть колишніх Європейських угод із країнами Центральної та Східної Європи, Угода про асоціацію з Україною не має на меті підготувати ії до вступу в ЄС.

Виходячи з цього, вбачається, що закріплення в Основному законі держави положень щодо її стратегічного руху до набуття повноправного членства в ЄС має пе- редусім зумовлюватися двостороннім характером такого руху, який зараз відсутній.

По-друге, попри те, що Основний закон у демократичному суспільстві має характеризуватися підвищеним ступенем стабільності, варто констатувати, що в нинішніх вітчизняних реаліях до тексту Конституції України досить часто вносилися зміни й доповнення на догоду певним політичним інтересам. Тому навіть закріплення в тексті Конституції України цих положень не гарантує повною мірою незмінність зовнішньополітичних пріоритетів держави в майбутньому.

По-третє, як бачимо, визначення й закріплення в Основному законі стратегічного зовнішньополітичного курсу України має передусім спиратися на волю українського народу, тому це питання варто було б винести на всенародне обговорення шляхом проведення всеукраїнського рефререндуму. Проте в умовах анексії й окупації частини території нашої держави Російською Федерацією залучення до таких заходів усіх українських громадян $є$ практично неможливим, а отже, навіть у випадку проведення референдуму, його результати не можна буде вважати повністю достовірними [5, с. 305-308].

ВИСнОВКИ. Отже, здійснення як змістовної, так і імплементаційної конституціоналізації асоціації України з ЄС можна реалізувати лише шляхом включення цього процесу безпосередньо в контекст конституційної реформи в Україні. Важливо усвідомити, що проведення конституційної реформи та встановлення асоціативних відносин із $€ С$ не варто розглядати як два паралельних напрями робіт, що ведуться в різних системах координат. Навпаки, лише максимальна синхронізація здійснюваних у межах цих напрямів заходів, визначення на обоюдній основі їхніх пріоритетів, координація й узгодження поточних завдань дозволять розробити комплексну стратегію конституційного реформування та нададуть конституційним перетворенням цілісного характеру. На нашу думку, інструментарій, закладений у політичній та економічній частинах Угоди про асоціацію, за умов його послідовного та прагматичного використання, може забезпечити реформування національних політико-правових і соціально-економічних інститутів в Україні з урахуванням національних інтересів.

Що стосується підтвердження європейської ідентичності Українського народу та визначення незворотності європейського вектора розвитку держави у преамбулі Конституції України, вважаємо, що це є дуже важливою, але лише початковою частиною набагато глобальнішого процесу, тільки вдалий і ретельний конституційний супровід якого стане запорукою поступового перетворення України на демократичну, правову державу.

\section{Список використаної літератури}

1. Задорожній О. В. Проекти реформування конституції України і міжнародне право / О.В.Задорожній. Український часопис міжнародного права. 2014. - № 3. - С. 29-41.

2. Бориславська О. Конституційна реформа як шлях формування в Україні конституційної системи обмеженого правління (на основі досвіду європейської моделі конституціоналізму) / О. Бориславська // Право України. - 2014. - № 7. - С. 47-54, 48

3. Угода про асоціацію між Україною, з однієї сторони, та Європейським Союзом, Європейським співтовариством з атомної енергії і їхніми державами-членами, з іншої сторони [Електронний ресурс]. Режим доступу : http://zakon3.rada.gov.ua/laws/show/984_011/paran2820\# n2820.

4. Стрєльцова О. В. Конституціоналізація процесу асоціації України 3 Європейським Союзом: теорія та практика : монографія / О. В. Стрєльцова . - К. : Алерта, 2017.

5. Стрєльцова О. В. Проблеми реформування Конституції України в контексті забезпечення європейської інтеграції. Конституційноправове будівництво на зламі епох: пошуки оптимальних моделей: Мат. 
міжнар. наук.-практ. конф. м. Ужгород, 3-4 травня 2019 / О. В. Стрєльцова. - Ужгород : Ужгород. нац. ун-т, 2019. - С. 305-308.

6. Марцеляк О. В. Конституційна реформа в Україні і конституціоналізація вітчизняної правової системи. Конституційно-правове будівництво на зламі епох: пошуки оптимальних моделей: Мат. міжнар. наук.-практ. конф. м. Ужгород, 22-23 квітня 2016 / О. В. Марцеляк. - Ужгород : Ужгород. нац. ун-т, 2016. - С. 71-73.

7. Терлецький Д. С. Конституційно-правове регулювання дії міжнародних договорів в Україні : дис. ... канд. юрид. наук: 12.00 .02 Д. С. Терлецький. - О., 2007. - С. 69-70.

8. Курс конституционного права Украины : учебник / М. А. Баймуратов и др. ; под ред. М. А. Баймуратова, А. В. Батанова. - Х. : Одиссей, 2008. - Т. 1. - С. 545-546.

9. Закон України "Про ратифікацію Угоди про асоціацію між Україною, з однієї сторони, та Європейським Союзом, Європейським співтовариством з атомної енергії і їхніми державами-членами, з іншої сторони" // Відомості Верховної Ради. - 2014. - № 40. - Ст. 2021.

10. Чи виконує Київ вимоги $€ С$ ? Частина 7: конституційна реформа // Європейська правда [Електронний ресурс]. - Режим доступу: http://www.eurointegration.com.ua/articles/2015/02/4/7030422/.

11. Прилуцький С. В. Модернізація статусу суддів: концепт взаємодії громадянського суспільства та держави в умовах конституційної реформи 2016 р. / С.В. Прилуцький, О. В. Стрєльцова // Публічне право. - 2016. - № 4 (24). - С. 9-17.

12. Декларація про державний суверенітет України (16 липня 1990 р.) // Відомості Верховної Ради УРСР (ВВР). - 1990. - № 31 . Ст. 429.

13. Муравйов В. Організаційно-правовий механізм реалізації Угоди про асоціацію між Україною та Європейським Союзом / В. Муравйов // Право України. - 2015. - № 8. - С. 17-31, 29.

References:

1. Zadorozhnii, O.V. (2014) Proekty reformuvannia konstytutsi Ukrainy i mizhnarodne pravo [Projects of reforming the constitution of Ukraine and international law]. Ukrainskyi chasopys mizhnarodnoho prava [Ukrainian Journal of International Law], (3), 29-41 (in Ukrainian)

2. Boryslavska, O. (2014) Konstytutsiina reforma yak shliakh formuvannia v Ukraini konstytutsiinoi systemy obmezhenoho pravlinnia (na osnovi dosvidu yevropeiskoi modeli konstytutsionalizmu) [Constitutional reform as a way of forming a constitutional system of limited government in Ukraine (based on the experience of the European model of constitutionalism)] Pravo Ukrainy [Law of Ukraine], (7), 47-54 (in Ukrainian).

3. Uhoda pro asotsiatsiiu mizh Ukrainoiu, z odniiei storony, ta Yevropeiskym Soiuzom, Yevropeiskym spivtovarystvom z atomnoi enerhii i yikhnimy derzhavamy-chlenamy, $z$ inshoi storony [The Association Agreement between Ukraine, of the one part, and the European Union, the European Atomic Energy Community and their Member States, of the other part]. http://zakon3.rada.gov.ua/laws/show/984_011/paran2820\#n2820 (in Ukrainian).

4. Strieltsova, O.V. (2017) Konstytutsionalizatsiia protsesu asotsiatsi Ukrainy z Yevropeiskym Soiuzom: teoriia ta praktyka [Constitutionalization of the process of association of Ukraine with the European Union: theory and practice]. Kyiv: Alerta (in Ukrainian).

5. Strieltsova, O.V. (2019) Problemy reformuvannia Konstytutsii Ukrainy $v$ konteksti zabezpechennia yevropeiskoi intehratsii [Problems of

O. Strieltsova, Dr of Law, Associate Prof

Taras Shevchenko National University of Kyiv, Kyiv, Ukraine reforming the Constitution of Ukraine in the context of ensuring European integration] U Konstytutsiino-pravove budivnytstvo na zlami epokh: poshuky optymalnykh modelei [Constitutional and legal construction at the turn of the epochs: search for optimal models] (S. 305-308). Uzhhorod: Uzhhorodskyi natsionalnyi universytet. (in Ukrainian)

6. Martseliak, O.V. (2016) Konstytutsiina reforma v Ukraini i konstytutsionalizatsiia vitchyznianoi pravovoi systemy [Constitutional reform in Ukraine and constitutionalization of the domestic legal system]. U Konstytutsiino-pravove budivnytstvo na zlami epokh: poshuky optymalnykh modelei [Constitutional and legal construction at the turn of the epochs: search for optimal models] (S. 71-73). Uzhhorod: Uzhhorodskyi natsionalnyi universytet (in Ukrainian)

7. Terletskyi, D.S. (2007) Konstytutsiino-pravove rehuliuvannia dii mizhnarodnykh dohovoriv $v$ Ukraini [Constitutional and legal regulation of international agreements in Ukraine] [dys. kand. yuryd. nauk]. Odesa [in Ukrainian].

8. Baimuratov, M.A., Batanov, A.V., Slydenko, Y.D., Kuranyn, V.A., Pedko, Yu.S (2008) Kurs konstytutsyonnoho prava Ukrayny [Course of constitutional law of Ukraine]. Eds. M.A. Baimuratov, A.V. Batanov. Kh.: Odyssei (in Russian).

9. Pro ratyfikatsiiu Uhody pro asotsiatsiiu mizh Ukrainoiu, z odniiei storony, ta Yevropeiskym Soiuzom, Yevropeiskym spivtovarystvom z atomnoi enerhii i yikhnimy derzhavamy-chlenamy, $z$ inshoi storony, Zakon Ukrainy [On Ratification of the Association Agreement between Ukraine, on the one hand, and the European Union, the European Atomic Energy Community and their Member States, on the other hand, Law of Ukraine] (2014). Vidomosti Verkhovnoi Rady, (40), 2021 (in Ukrainian).

10. Chy vykonuie Kyiv vymohy YeS? Chastyna 7: konstytutsiina reforma [Does Kyiv meet EU requirements? Part 7: constitutional reform]. Yevropeiska pravda [European truth]. URL: http://www.eurointegration.com.ua/ articles/2015/02/4/7030422/. [in Ukrainian].

11. Prylutskyi, S.V., Strieltsova, O.V. (2016) Modernizatsiia statusu suddiv: kontsept vzaiemodii hromadianskoho suspilstva ta derzhavy $v$ umovakh konstytutsiinoi reformy 2016 roku [Modernization of the status of judges: the concept of interaction between civil society and the state in the context of the 2016 constitutional reform]. Publichne pravo. [Public law], (4 (24), 9-17 (in Ukrainian).

12. Deklaratsiia pro derzhavnyi suverenitet Ukrainy [Declaration of State Sovereignty of Ukraine] (1990). Vidomosti Verkhovnoi Rady URSR [Information of the Verkhovna Rada of the USSR] (31), 429. (in Ukrainian).

13. Muraviov, V. (2015) Orhanizatsiino-pravovyi mekhanizm realizatsii hody pro asotsiatsiiu mizh Ukrainoiu ta Yevropeiskym Soiuzom [Organizational and legal mechanism for implementing the Association Agreement between Ukraine and the European Union] (2015). Pravo Ukrainy [Law of Ukraine], (8), 17-31 (in Ukrainian).

Received: $04 / 01 / 2021$

1st revision: $08 / 02 / 2021$

Accepted: $22 / 02 / 2021$

\section{CONSTITUTIONALIZATION OF UKRAINE-EU COOPERATION ON THE BASIS OF THE ASSOCIATION AGREEMENT: DEVELOPMENT PROSPECTS}

The article studies the process of constitutionalization of associative relations between Ukraine and the European Union. The author distinguishes and reveals two significant aspects of this process, namely meaningful and implementing.

It is determined that meaningful constitutionalization by its essence is the constitutional modernization, where the meaningful updating of the Constitutional provisions is made in order to form the constitutional pillars for further democratization of social and political life in Ukraine, the approximation of the national political and legal system in accordance with the European values and principles, the improvement of the internal legal framework. The implementing aspect of constitutionalization means the purposeful formation of constitutional preconditions for the implementation of Association Agreement's provisions to the national legal system. The author stipulates that the fulfillment of both meaningful and implementing aspects of constitutionalization of Ukraine's association with the EU shall be implemented mainly by incorporating of this process directly into the context of the constitutional reform in Ukraine.

The special attention is paid to certain problems of the reformation of the Constitution of Ukraine ensuring the European integration. The author expresses the critical reservations related to the amendments to the Constitution with the provisions of strategic orientation of Ukraine for the long term perspective.

Keywords: Constitution of Ukraine, Constitutional Reform, Constitutionalization, European Union, Association Agreement between Ukraine and the EU. 